\title{
Lower Sensitivity to Stress and Altered Monoaminergic Neuronal Function in Mice Lacking the NMDA Receptor $\epsilon 4$ Subunit
}

\author{
Yoshiaki Miyamoto, ${ }^{1}$ Kiyofumi Yamada, ${ }^{1}$ Yukihiro Noda, ${ }^{1}$ Hisashi Mori, ${ }^{2}$ Masayoshi Mishina, ${ }^{2}$ and \\ Toshitaka Nabeshima ${ }^{1}$ \\ 1 Department of Neuropsychopharmacology and Hospital Pharmacy, Nagoya University Graduate School of Medicine, \\ Showa-ku, Nagoya 466-8560, Japan, and 2Department of Molecular Neurobiology and Pharmacology, School of \\ Medicine, University of Tokyo, Bunkyou-Ku, Tokyo 113-0033, Japan
}

NMDA receptors, an ionotropic subtype of glutamate receptors (GluRs), play an important role in excitatory neurotransmission, synaptic plasticity, and brain development. They are composed of the GluR $\zeta$ subunit (NR1) combined with any one of four GluR $\epsilon$ subunits (GluR $\epsilon 1-$ GluR $\epsilon$; NR2A-NR2D). Although the GluR $\zeta$ subunit exists in the majority of the CNS throughout all stages of development, the GluR $\epsilon$ subunits are expressed in distinct temporal and spatial patterns. In the present study, we investigated neuronal functions in mice lacking the embryonic GluR $\epsilon 4$ subunit. GluR $\epsilon 4$ mutant mice exhibited reductions of $\left[{ }^{3} \mathrm{H}\right] \mathrm{MK}-801[(+)-5-$ methyl-10,11-dihydro-5H-dibenzo [a,d] cyclohepten-5,10-imine maleate] binding and ${ }^{45} \mathrm{Ca}^{2+}$ uptake through the NMDA receptors. The expression of GluR $\zeta$ subunit protein, but not GluR $\epsilon 1$ and GluRe2 subunit proteins, was reduced in the frontal cortex and striatum of the mutant mice. A postmortem examination in GluRe4 mutant mice revealed that tissue contents of norepinephrine, do- pamine, serotonin, and their metabolites were reduced in the hippocampus and that dopamine, as well as serotonin, metabolism was upregulated in the frontal cortex, striatum, hippocampus, and thalamus. To clarify the phenotypical influences of the alteration in neuronal functions, performances in various behavioral tests were examined. GluR $\epsilon 4$ mutant mice showed reduced spontaneous locomotor activity in a novel environment and less sensitivity to stress induced by the elevated plus-maze, lightdark box, and forced swimming tests. These findings suggest that GluR $\epsilon 4$ mutant mice have dysfunctional NMDA receptors and altered emotional behavior probably caused by changes in monoaminergic neuronal activities in adulthood.

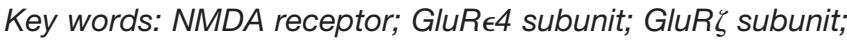
monoaminergic neuronal systems; locomotor activity; emotional behavior
Glutamate receptors (GluRs) play an important role in excitatory neurotransmission, synaptic plasticity, neuronal development, and neurodegenaration of the CNS. They are divided in two general groups: ionotropic GluRs form ligand-gated cation channels and are subdivided into NMDA, AMPA, and kainate receptors, whereas metabotropic GluRs link G-protein that modulates the production of intracellular messengers (Hollmann and Heinemann, 1994; Nakanishi and Masu, 1994; Pin and Duvoisin, 1995).

NMDA receptors are thought to be a critical subtype mediating glutamate actions in the CNS. They are coupled with inherent high $\mathrm{Ca}^{2+}$-permeable channels, which are formed by assembly of the GluR $\zeta$ subunit (NR1) and any one of four GluR $\epsilon$ subunits (GluR $\epsilon 1-$ Glu $\epsilon$ R4; NR2A-NR2D). Although the GluR $\zeta$ subunit exists in the brain at all developmental stages, the GluR $\epsilon$ subunits are expressed in distinct temporal and spatial patterns (Mayer and Westbrook, 1987; Hollmann and Heine-

\footnotetext{
Received July 31, 2001; revised Nov. 14, 2001; accepted Dec. 18, 2001.

This work was supported in part by Grant-in-Aid for Scientific Research 10044260 from the Ministry of Education, Science, Sports, and Culture of Japan and by Special Coordination Funds for Promoting Science and Technology, Target-Oriented Brain Science Research Program from the Ministry of Education, Culture, Sports, Science, and Technology of Japan.

Correspondence should be addressed to Dr. Toshitaka Nabeshima, Department of Neuropsychopharmacology and Hospital Pharmacy, Nagoya University Graduate School of Medicine, 65 Tsuruma-cho, Showa-ku, Nagoya 466-8560, Japan. E-mail: tnabeshi@med.nagoya-u.ac.jp.

Y. Miyamoto's present address: Department of Molecular Genetics, National Institute for Longevity Sciences, Gengo 36-3, Morioka-cho, Oobu, Aichi 474-8522, Japan.

Copyright (C) 2002 Society for Neuroscience $\quad 0270-6474 / 02 / 222335-08 \$ 15.00 / 0$
}

mann, 1994; Nakanishi and Masu, 1994). Prenatal NMDA receptors include the GluRe2 and/or GluR $\epsilon 4$ subunit, whereas the GluR $\epsilon 1$ and GluR $\epsilon 3$ subunits appear only after birth, the former being expressed predominantly in the forebrain and the latter mainly in the cerebellum (Watanabe et al., 1992; Monyer et al., 1994). Thus, the GluR $\epsilon$ subunits provide the molecular diversity in NMDA receptors during development and in various regions of the brain.

The physiological significance of NMDA receptor subunits has been demonstrated in knock-out mice. Although disruption of the GluR $\epsilon 2$ subunit caused perinatally death (Kutsuwada et al., 1996), mice lacking the embryonic GluR $\epsilon 4$ subunit are viable and exhibit reduced spontaneous locomotor activity (Ikeda et al., 1995). The impairment of spatial and contextual learning was demonstrated in GluR $\epsilon 1$ mutant mice (Sakimura et al., 1995; Kiyama et al., 1998), but no deficits were observed in GluR€3 mutant mice (Ebralidze et al., 1996). GluR $\zeta$ mutant mice showed a deficit of all NMDA receptors and perinatal death (Forrest et al., 1994; Li et al., 1994). These findings suggest that the GluR $\epsilon$ subunits are major determinants of the functional properties of NMDA receptors, whereas the GluR $\zeta$ subunit is an essential molecule in functional NMDA receptors and in brain development.

Accordingly, we investigated the alteration of neuronal functions in mice lacking NMDA receptor subunits. In GluR $\epsilon 1 \mathrm{mu}$ tant mice, NMDA receptor function was significantly reduced, but the dopaminergic neuronal activity was increased because of disinhibition of inhibitory GABAergic input. Furthermore, 
GluR $\epsilon 1$ mutant mice showed an enhancement of locomotor activity in a novel environment, which is attributed to hyperfunction of dopaminergic neuronal system (Miyamoto et al., 2001). In the present study, we investigated the alteration of neuronal functions in adult mice lacking the embryonic GluR $\epsilon 4$ subunit. $\left[{ }^{3} \mathrm{H}\right] \mathrm{MK}-801$ [(+)-5-methyl-10,11-dihydro-5H-dibenzo [a,d] cyclohepten-5,10imine maleate] binding and ${ }^{45} \mathrm{Ca}^{2+}$ uptake through the NMDA receptors were measured to elucidate the role of the GluRe4 subunit in NMDA receptor function. Because the functional alteration of NMDA receptors in vivo has been reported to affect monoaminergic neuronal function and behavior (Hiramatsu et al., 1989; Imperato et al., 1990; Miller and Abercrombie, 1996), monoamine metabolism, locomotor activity, and emotional behavior in GluR $\epsilon 4$ mutant mice were also assessed.

\section{MATERIALS AND METHODS}

Animals. Mutant mice lacking the GluR $\epsilon 4$ subunit of NMDA receptors were provided by Prof. M. Mishina (Ikeda et al., 1995). The homozygous GluR $\epsilon 4$ mutant (-/-; 3 months old) and the wild-type (+/+; 3 months old) mice used in this study were obtained by crossing F11 heterozygous GluR $\epsilon 4$ mutant mice $(+/-)$ having a $99.99 \%$ pure C57BL/6 genetic background. The genotypes of mice were determined by Southern blotting analyses of tail DNA as described by Ikeda et al. (1995). The animals were housed in plastic cages and were kept in a regulated environment $\left(24 \pm 1{ }^{\circ} \mathrm{C}, 50 \pm 5 \%\right.$ humidity), with a $12 \mathrm{hr}$ light/dark cycle (lights on at 9:00 A.M.). Food and tap water were available ad libitum. All experiments were performed in accordance with the Guidelines for Animal Experiments of the Nagoya University School of Medicine. The procedures involving animals and their care were conducted in conformity with the international guidelines Principles of Laboratory Animal Care (National Institutes of Health publication 85-23, revised 1985).

$\left[{ }^{3} H\right] M K-801$ binding. The GluR $\epsilon 4$ mutant mice and the wild-type mice were killed by decapitation, and brains were quickly removed and placed on an ice-cold glass plate. The forebrain (whole brain minus the cerebellum and brainstem) was rapidly dissected out, frozen, and stored in a deep freezer at $-80^{\circ} \mathrm{C}$ until assayed. $\left[{ }^{3} \mathrm{H}\right] \mathrm{MK}-801$ binding was measured as described previously (Yoneda and Ogita, 1989, 1991), with a minor modification (Miyamoto et al., 2001). Briefly, frozen samples were thawed at room temperature and homogenized in $40 \mathrm{vol}$ of $50 \mathrm{~mm}$ Tris-acetate buffer, $\mathrm{pH}$ 7.4, containing 1 mm EDTA using a Physcotron homogenizer. All additional procedures were performed at $4^{\circ} \mathrm{C}$. The homogenates were centrifuged at $40,000 \times g$ for $30 \mathrm{~min}$, and resultant pellets were washed three times with the same volume of $50 \mathrm{~mm}$ Trisacetate buffer. The final pellets were suspended in $30 \mathrm{vol}$ of $0.32 \mathrm{M}$ sucrose, and the suspensions were frozen at $-80^{\circ} \mathrm{C}$ for no longer than 1 week until use. On the day of the experiments, the frozen suspensions were thawed at room temperature and treated with $0.08 \%$ Triton X-100 at $4^{\circ} \mathrm{C}$ (an approximate protein concentration of $0.32 \mathrm{mg} / \mathrm{ml}$ ) for $10 \mathrm{~min}$ with gentle stirring. The treatment was terminated by centrifugation at $40,000 \times g$ for $30 \mathrm{~min}$, and pellets were washed five times with $40 \mathrm{vol}$ of $50 \mathrm{~mm}$ Tris-acetate buffer, followed by centrif ugation at $40,000 \times \mathrm{g}$ for 30 min. For determination of $\left[{ }^{3} \mathrm{H}\right] \mathrm{MK}-801$ binding, an aliquot $(0.3 \mathrm{mg}$ of protein) of the membrane preparations was incubated, in the presence or absence of glutamate $(10 \mu \mathrm{M})$, glycine $(10 \mu \mathrm{M})$, and spermidine $(1 \mathrm{mM})$, with $5 \mathrm{~nm}(+)\left[3-{ }^{3} \mathrm{H}\right] \mathrm{MK}-801(22.5 \mathrm{Ci} / \mathrm{mmol}$; NEN Life Science Products, Boston, MA) in a total volume of $0.5 \mathrm{ml}$ of $50 \mathrm{~mm}$ Tris-acetate buffer at $30^{\circ} \mathrm{C}$ for $16 \mathrm{hr}$. The incubation was terminated by the addition of $3 \mathrm{ml}$ of ice-cold $50 \mathrm{~mm}$ Tris-acetate buffer and subsequent filtration through a Whatman GF/B glass filter under a constant vacuum. The filter was rinsed with the same volume of ice-cold $50 \mathrm{~mm}$ Tris-acetate buffer three times within $10 \mathrm{sec}$. The radioactivity retained on the filter was measured by liquid scintillation spectrophotometry, at a counting efficiency of $57-59 \%$. Nonspecific binding was determined with $0.1 \mathrm{~mm}$ cold (+)MK-801 (Sigma, St. Louis, MO), and the specific binding accounted for $>60 \%$ of the total binding found in the absence of cold (+)MK-801.

${ }^{45} \mathrm{Ca}^{2+}$ uptake. ${ }^{45} \mathrm{Ca}^{2+}$ uptake through the NMDA receptors was measured as described by Miyamoto et al. (2001). The GluR $\epsilon 4$ mutant mice and the wild-type mice were killed by decapitation, the brains were quickly removed, and the forebrain (whole brain minus the cerebellum and brainstem) was dissected out on an ice-cold glass plate. The forebrains were homogenized in $20 \mathrm{vol}$ of ice-cold $0.32 \mathrm{M}$ sucrose at $4^{\circ} \mathrm{C}$ in a Teflon glass homogenizer. All additional procedures were performed at $4^{\circ} \mathrm{C}$. The homogenates were centrifuged at $1000 \times g$ for $10 \mathrm{~min}$. The supernatants were collected and then diluted 1:1 with basal buffer of the following composition (in $\mathrm{mM}$ ): $135 \mathrm{NaCl}, 5 \mathrm{KCl}, 1 \mathrm{CaCl}_{2}$, and 10 HEPES, pH adjusted to 7.4 with Tris base, and centrifuged at $10,000 \times$ $g$ for $15 \mathrm{~min}$. The pellets were resuspended in basal buffer and used for the ${ }^{45} \mathrm{Ca}^{2+}$ uptake assay. The synaptosome suspension $(0.5 \mathrm{mg}$ of protein) was preincubated in a total volume of $450 \mu \mathrm{l}$ of basal buffer, in the presence or absence of $(+) \mathrm{MK}-801(100 \mu \mathrm{M})$, at $37^{\circ} \mathrm{C}$ for $10 \mathrm{~min}$. The ${ }^{45} \mathrm{Ca}^{2+}$ uptake assay was initiated by adding $50 \mu$ lof prewarmed basal buffer containing $1 \mu \mathrm{Ci} / \mathrm{ml}^{45} \mathrm{CaCl}_{2}(18.1 \mathrm{mCi} / \mathrm{mg}$; NEN Life Science Products), in the presence or absence of NMDA $(100 \mu \mathrm{M})$, glycine $(10$ $\mu \mathrm{M})$, and spermidine $(1 \mathrm{~mm})$ or high $\mathrm{K}^{+}(45 \mathrm{~mm}$; isomolar replacement of $\mathrm{NaCl}$ with $\mathrm{KCl}$ ). The reaction was terminated after 5 min by adding $3 \mathrm{ml}$ of ice-cold basal buffer. The mixture was rapidly filtered under vacuum over Whatman $\mathrm{GF} / \mathrm{B}$ glass filters, and the filters were rinsed twice with $3 \mathrm{ml}$ of basal buffer. The radioactivity was determined by liquid scintillation spectrophotometry at a counting efficiency of $90 \%$. $\mathrm{Ca}^{2+}$ uptake was defined by subtracting the uptake at $4^{\circ} \mathrm{C}$.

Western blot analysis. The GluR $\epsilon 4$ mutant mice and the wild-type mice were killed by decapitation, the brains were quickly removed, and the frontal cortex, striatum, hippocampus, and thalamus were dissected out on an ice-cold glass plate according to the method of Glowinski and Iversen (1966). Each section was homogenized with an ultrasonic processor in 10 vol of buffer ( $10 \mathrm{~mm}$ Tris-Cl, $\mathrm{pH} 7.2,5 \mathrm{~mm}$ EDTA, $0.32 \mathrm{M}$ sucrose, $1 \mathrm{~mm}$ phenylmethylsulfonyl fluoride, and $10 \mathrm{mg} / 1$ leupeptin) within $3 \mathrm{~min}$ of decapitation. The homogenates were centrifuged at $1000 \times g$ for $10 \mathrm{~min}$ at $4^{\circ} \mathrm{C}$ to obtain a postnuclear fraction. Protein determinations were made by the method of Lowry et al. (1951). The supernatants of $50 \mu \mathrm{g}$ of protein were electrophoresed in a $7.5 \%$ SDSpolyacrylamide gel, transferred to polyvinylidene difluoride membrane, and incubated with a 1:1000 dilution of GluR $\zeta$, GluR $\epsilon 1$, or GluR $\epsilon 2$ polyclonal antibody (Santa Cruz Biotechnology, Santa Cruz, CA). Antibody binding was detected by peroxidase-labeled secondary antibodies and the ECL detection kit (Amersham Biosciences, Arlington Heights, IL). The films were quantitated with a densitometer.

Contents of monoamines and their metabolites. The GluR $\epsilon 4$ mutant mice and the wild-type mice were killed by focused microwave irradiation for $1.5 \mathrm{sec}$ at $5 \mathrm{~kW}$, the brains were quickly removed, and the frontal cortex, striatum, hippocampus, and thalamus were dissected out on an ice-cold glass plate according to the method of Glowinski and Iversen (1966). Each section was rapidly frozen and stored in a deep freezer at $-80^{\circ} \mathrm{C}$ until assayed. The contents of monoamines and their metabolites were determined using an HPLC system with an electrochemical detector (Eicom, Kyoto, Japan), as described by Noda et al. (1998), with a minor modification (Miyamoto et al., 2001). Briefly, each frozen brain sample was weighed and homogenized with an ultrasonic processor in $350 \mu \mathrm{l}$ of $0.2 \mathrm{M}$ perchloric acid containing isoproterenol as an internal standard. The homogenates were placed on ice for $30 \mathrm{~min}$ and centrifuged at $20,000 \times g$ for $15 \mathrm{~min}$ at $4^{\circ} \mathrm{C}$. The supernatants were mixed with $1 \mathrm{M}$ sodium acetate to adjust the $\mathrm{pH}$ to 3.0 and injected into an HPLC system equipped with a reversed-phase ODS-column (Eicompak MA-5 ODS; $4.6 \times 150 \mathrm{~mm}$; Eicom) and an electrochemical detector. The column temperature was maintained at $25^{\circ} \mathrm{C}$, and the detector potential was set at $+750 \mathrm{mV}$. The mobile phase was $0.1 \mathrm{M}$ citric acid and $0.1 \mathrm{M}$ sodium acetate, $\mathrm{pH} 3.6$, containing $14 \%$ methanol, $180 \mathrm{mg} / 1$ sodium-Loctanesulfonate, and $5 \mathrm{mg} / \mathrm{l}$ EDTA, and the flow rate was set at 1 $\mathrm{ml} / \mathrm{min}$. The turnover of monoamines was calculated from the concentrations of each monoamine and its metabolite.

Behavioral analyses. To measure locomotor activity in a novel environment, a mouse was placed in a transparent acrylic cage with a black frosting Plexiglas floor $(45 \times 26 \times 40 \mathrm{~cm})$, and locomotion and rearing were measured every $5 \mathrm{~min}$ for $30 \mathrm{~min}$ using digital counters with infrared sensors (Scanet SV-10; Toyo Sangyo Co. Ltd., Toyama, Japan).

The elevated plus-maze consisted of two open $(25 \times 8 \times 0.5 \mathrm{~cm})$ and two closed $(25 \times 8 \times 20 \mathrm{~cm})$ arms emanating from a common central platform $(8 \times 8 \mathrm{~cm})$ to form a plus shape (Yamada et al., 2000). The entire apparatus was elevated to a height of $50 \mathrm{~cm}$ above floor level. The test was started by placing a mouse on the central platform of the maze facing an open arm, and a 5 min test duration was used. Conventional parameters consisted of the frequency of entry to open and closed arms. These data were used to calculate the percentage of open arms entries [i.e., (open arms entries/open and closed arms entries) $\times 100]$.

The light-dark box consisted of two compartments: a transparent Plexiglas box with a white frosting Plexiglas floor and a black Plexiglas box with a black frosting Plexiglas floor (both $15 \times 15 \times 15 \mathrm{~cm}$ ). Each box 


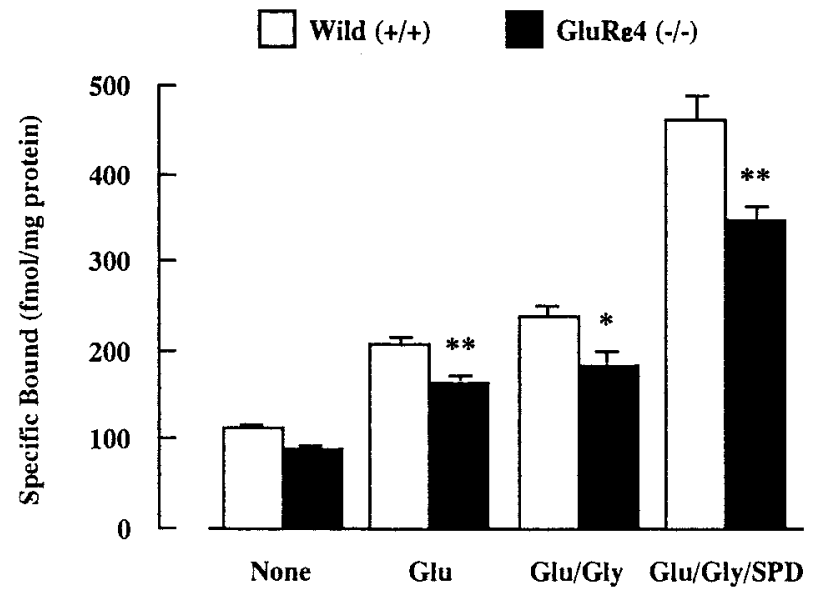

Figure 1. $\left[{ }^{3} \mathrm{H}\right] \mathrm{MK}-801$ binding in forebrain synaptic membranes of adult GluR $\epsilon 4$ mutant mice. Triton X-100-treated forebrain synaptic membranes were incubated with $5 \mathrm{~nm}\left[{ }^{3} \mathrm{H}\right] \mathrm{MK}-801$ at $30^{\circ} \mathrm{C}$ for $16 \mathrm{hr}$, in the presence or absence of $10 \mu \mathrm{M}$ glutamate (Glu), Glu plus $10 \mu \mathrm{M}$ glycine (Gly), or Glu plus Gly plus $1 \mathrm{~mm}$ spermidine $(S P D)$. Each column represents the mean $\pm \operatorname{SEM}(n=6) .{ }^{*} p<0.05$ and $* * p<0.01$ versus wild-type $(+/+)$.

could be divided by a sliding door $(10 \times 5 \mathrm{~cm}$ high $)$. The test was started by placing a mouse in the black Plexiglas box. The amounts of time spent in the transparent and black Plexiglas boxes was measured for $10 \mathrm{~min}$ using digital counters with infrared sensors (Scanet SV-10 LD; Toyo Sangyo Co. Ltd.). These data were used to calculate the percentage of time spent in the light box [i.e., (time spent in transparent Plexiglas box/time spent in transparent and black Plexiglas boxes) $\times 100$ ].

In the forced swimming test, a mouse was placed in a transparent glass cylinder $\left(8 \mathrm{~cm}\right.$ in diameter $\times 20 \mathrm{~cm}$ high), which contained water at $25^{\circ} \mathrm{C}$ to a depth of $8 \mathrm{~cm}$, and was forced to swim for $10 \mathrm{~min}$. The duration of immobility was measured every $1 \mathrm{~min}$ using digital counters with infrared sensors (Scanet MV-10 AQ; Toyo Sangyo Co. Ltd.), as described previously (Noda et al., 1995).

Statistical analysis. All data were expressed as the mean \pm SEM. Statistical differences between the GluR $\epsilon 4$ mutant mice and the wildtype mice were determined with Student's $t$ comparison test. In the analysis of locomotion and rearing curves, statistical differences between the GluR $\epsilon 4$ mutant mice and the wild-type mice were determined by an ANOVA with repeated measures.

\section{RESULTS}

\section{Function of NMDA receptors in adult GluRe4 mutant mice}

To demonstrate the functional changes in NMDA receptors of adult GluR $\epsilon 4$ mutant mice, we first measured the binding activity of $\left[{ }^{3} \mathrm{H}\right] \mathrm{MK}-801$, which is known as a noncompetitive antagonist for NMDA receptors, in synaptic membranes of the forebrain (whole brain minus the cerebellum and brainstem) treated with Triton X-100 to deplete endogenous amino acids (Fig. 1). The specific binding of $\left[{ }^{3} \mathrm{H}\right] \mathrm{MK}-801$ in both wild-type and mutant mice was increased when the assay was performed in the presence of activators for NMDA receptors such as glutamate $(10 \mu \mathrm{M})$, glycine $(10 \mu \mathrm{M})$, and spermidine $(1 \mathrm{mM})$. In the presence of glutamate, glutamate plus glycine, or glutamate plus glycine plus spermidine, the specific binding of $\left[{ }^{3} \mathrm{H}\right] \mathrm{MK}-801$ was significantly lower in GluR $\epsilon 4$ mutant mice than wild-type mice. Treatment with glycine or spermidine alone did not affect the basal-specific binding of $\left[{ }^{3} \mathrm{H}\right] \mathrm{MK}-801$ in either of the mice (data not shown).

We next measured NMDA-stimulated ${ }^{45} \mathrm{Ca}^{2+}$ uptake into synaptosomes of the forebrain (whole brain minus the cerebellum and brainstem) (Fig. 2). There was no difference in the basal level of ${ }^{45} \mathrm{Ca}^{2+}$ uptake between wild-type $(12.7 \pm 0.1 \mathrm{nmol} / \mathrm{mg}$ protein per $5 \mathrm{~min})$ and GluR $\epsilon 4$ mutant $(12.8 \pm 0.2 \mathrm{nmol} / \mathrm{mg}$ protein

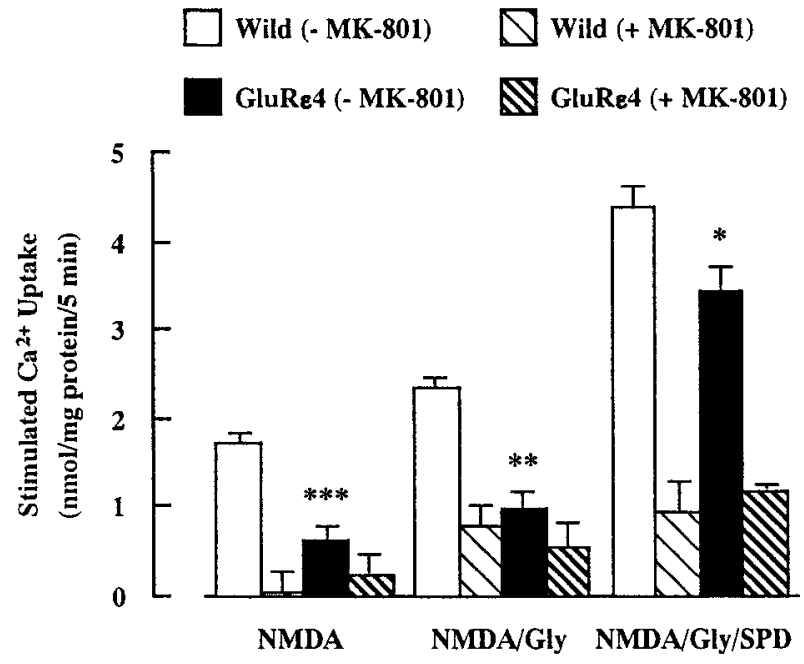

Figure 2. NMDA-stimulated ${ }^{45} \mathrm{Ca}^{2+}$ uptake into forebrain synaptosomes of adult GluR $\epsilon 4$ mutant mice. The forebrain synaptosomes were preincubated at $37^{\circ} \mathrm{C}$ for $10 \mathrm{~min}$, in the presence or absence of $100 \mu \mathrm{M}$ MK-801. The assay was initiated by adding prewarmed buffer containing $1 \mu \mathrm{Ci} / \mathrm{ml}^{45} \mathrm{CaCl}_{2}$ for $5 \mathrm{~min}$, in the presence of $100 \mu \mathrm{M} \mathrm{NMDA}$, NMDA plus $10 \mu \mathrm{M}$ glycine $(G l y)$, or NMDA plus Gly plus $1 \mathrm{mM}$ spermidine $(S P D)$. Each column represents the mean \pm SEM $(n=8$ for $-\mathrm{MK}-801$ group; $n=6$ for + MK-801 group). $* p<0.05$, ** $p<0.01$, and $* * * p<$ 0.001 versus wild-type (-MK-801).

per $5 \mathrm{~min}$ ) mice. When the assay was performed in the presence of NMDA $(100 \mu \mathrm{M})$, NMDA plus glycine $(10 \mu \mathrm{M})$, or NMDA plus glycine plus spermidine $(1 \mathrm{mM}),{ }^{45} \mathrm{Ca}^{2+}$ uptake was increased in both groups. However, there was significantly less ${ }^{45} \mathrm{Ca}^{2+}$ uptake in GluR $\epsilon 4$ mutant mice than in wild-type mice under these stimulated conditions. The NMDA-, glycine-, and/or spermidine-stimulated ${ }^{45} \mathrm{Ca}^{2+}$ uptake in both groups was antagonized by the pretreatment with MK-801 $(100 \mu \mathrm{M})$. On the other hand, there was no difference in high $\mathrm{K}^{+}(45 \mathrm{~mm})$-stimulated ${ }^{45} \mathrm{Ca}^{2+}$ uptake between wild-type $(6.5 \pm 0.2 \mathrm{nmol} / \mathrm{mg}$ protein per $5 \mathrm{~min})$ and GluR $\epsilon 4$ mutant $(6.8 \pm 0.4 \mathrm{nmol} / \mathrm{mg}$ protein per $5 \mathrm{~min})$ mice. The results on $\left[{ }^{3} \mathrm{H}\right] \mathrm{MK}-801$ binding and NMDAstimulated ${ }^{45} \mathrm{Ca}^{2+}$ uptake suggest that the function of NMDA receptors is reduced in adult GluR $\epsilon 4$ mutant mice.

\section{Expression of NMDA receptor subunit in adult GluR $€ 4$ mutant mice}

As demonstrated above, a defect in the embryonic GluR $\epsilon 4$ subunit results in an impairment of NMDA receptor function in adulthood ( 3 months old). Because the GluR $\epsilon 4$ subunit is expressed predominantly at the prenatal stage, but not at the postnatal stage, these findings suggest that disruption of the GluR $\epsilon 4$ subunit affects the expression of other GluR subunits composing NMDA receptors in adult animals. To test this possibility, the expression of other subunit proteins forming NMDA receptors was analyzed by Western blotting in adult GluR $\epsilon 4$ mutant mice (Fig. 3). The amount of GluR $\zeta$ subunit protein, an essential molecule for functional NMDA receptors in vivo, was selectively reduced in the frontal cortex and striatum, but not in the hippocampus and thalamus, of GluR $\epsilon 4$ mutant mice (Fig. $3 A$ ). There was no significant difference in GluR $\epsilon 1$ and GluR $\epsilon 2$ subunit protein levels in any region between wild-type and GluR $\epsilon 4 \mathrm{mu}-$ tant mice (Fig. 3B,C). These findings indicate that NMDA receptor subunit composition or the amount of functional NMDA receptors may be altered in adult GluR $\epsilon 4$ mutant mice, which results in the malfunction of NMDA receptors. 


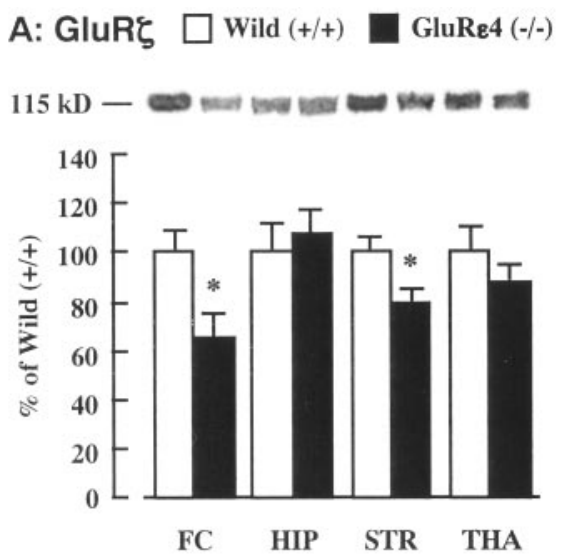

B: GluRe1

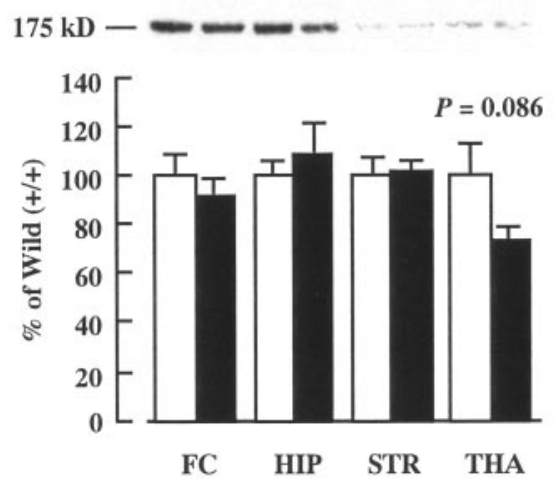

\section{C: GluRe2}

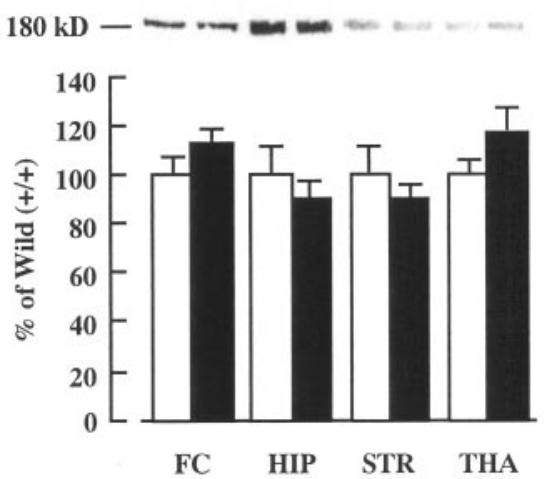

Figure 3. Expression of NMDA receptor subunit proteins in various regions of the adult GluR $\epsilon 4$ mutant mouse brain. The amount of each NMDA receptor subunit was determined by Western blot analysis using antibodies against GluR $\zeta$, GluR $\epsilon 1$, or GluR $\epsilon 2$. The synaptosomal protein samples were prepared from various regions of the adult GluR $\epsilon 4$ mutant mouse brain. FC, Frontal cortex; HIP, hippocampus; STR, striatum; THA, thalamus. Each column represents the mean $\pm \operatorname{SEM}(n=4) .{ }^{*} p<0.05$ versus wild-type $(+/+)$.

\begin{tabular}{|c|c|c|c|c|c|c|c|}
\hline & $\mathrm{NE}$ & MHPG & DA & DOPAC & HVA & $5-\mathrm{HT}$ & 5-HIAA \\
\hline \multicolumn{8}{|l|}{$\mathrm{FC}$} \\
\hline Wild $(+/+)$ & $683.9 \pm 28.8$ & $0.63 \pm 0.03$ & $21.8 \pm 1.09$ & $27.4 \pm 1.23$ & $74.3 \pm 3.19$ & $189.7 \pm 8.35$ & $195.0 \pm 10.3$ \\
\hline $\operatorname{GluR} \in 4(-/-)$ & $740.1 \pm 27.4$ & $0.47 \pm 0.02 * *$ & $15.7 \pm 0.55^{* *}$ & $30.2 \pm 1.36$ & $96.6 \pm 2.64 * *$ & $210.0 \pm 8.28$ & $282.1 \pm 11.0^{* *}$ \\
\hline \multicolumn{8}{|l|}{ STR } \\
\hline Wild $(+/+)$ & $293.4 \pm 24.2$ & $11.3 \pm 0.79$ & $12335.5 \pm 113.2$ & $2034.3 \pm 96.2$ & $1494.6 \pm 62.4$ & $370.3 \pm 17.3$ & $1168.7 \pm 63.3$ \\
\hline GluR $\epsilon 4(-/-)$ & $195.9 \pm 17.6^{* *}$ & $11.4 \pm 0.64$ & $12371.8 \pm 100.8$ & $2407.5 \pm 87.7^{*}$ & $1840.0 \pm 43.5^{* *}$ & $438.0 \pm 19.8^{*}$ & $1747.9 \pm 67.8^{* *}$ \\
\hline \multicolumn{8}{|l|}{ HIP } \\
\hline Wild $(+/+)$ & $732.1 \pm 22.4$ & $4.01 \pm 0.26$ & $2.70 \pm 0.43$ & $10.2 \pm 2.28$ & $38.4 \pm 3.24$ & $581.8 \pm 23.0$ & $1269.0 \pm 50.2$ \\
\hline $\operatorname{GluR} \in 4(-/-)$ & $390.1 \pm 27.2^{* *}$ & $1.28 \pm 0.18^{* *}$ & $0.59 \pm 0.02^{* *}$ & $3.60 \pm 0.84^{*}$ & $23.9 \pm 2.03^{* *}$ & $290.5 \pm 24.4^{* *}$ & $806.9 \pm 24.2^{* *}$ \\
\hline \multicolumn{8}{|l|}{ THA } \\
\hline Wild $(+/+)$ & $1403.6 \pm 39.6$ & $5.15 \pm 0.17$ & $216.5 \pm 21.3$ & $223.8 \pm 14.7$ & $329.5 \pm 21.5$ & $887.0 \pm 16.6$ & $1530.3 \pm 76.1$ \\
\hline GluRe4 (-/-) & $1356.5 \pm 69.8$ & $5.55 \pm 0.22$ & $192.7 \pm 12.9$ & $264.4 \pm 22.0$ & $390.2 \pm 21.6$ & $831.7 \pm 22.0$ & $1756.7 \pm 78.5$ \\
\hline
\end{tabular}

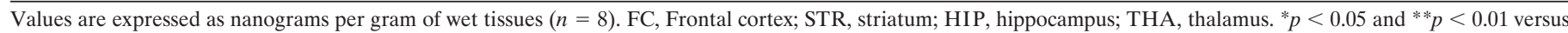
wild-type $(+/+)$.

\section{Monoaminergic neuronal function in adult GluRe4 mutant mice}

To investigate whether targeted disruption of the embryonic GluR $\epsilon 4$ subunit gene would affect the function of monoaminergic neuronal systems, the tissue contents of monoamines and their metabolites in various regions of the adult GluR $\epsilon 4$ mutant mouse brain were measured (Table 1). A marked reduction of norepinephrine (NE), dopamine (DA), and serotonin (5-hydroxytryptamine; 5-HT) contents, being 53, 22, and 50\% of that in wildtype mice, respectively, was evident in the hippocampus of the mutant mice. Metabolite levels were also reduced in this region. In addition, DA in the frontal cortex and NE in the striatum decreased significantly, whereas 5-HT in the striatum increased in the mutant mice compared with the wild-type mice. To address the functional alterations of monoaminergic neuronal systems, monoamine metabolism was evaluated by calculating the ratio of the tissue content of the monoamines to their metabolites (Fig. 4). The ratio of 3,4-dihydroxyphenylacetic acid (DOPAC) to DA and/or of homovanillic acid (HVA) to DA in the frontal cortex, striatum, hippocampus, and thalamus was significantly increased in GluRe4 mutant mice compared with wild-type mice (Fig. $4 A-D)$. In the same regions, the ratio of 5-hydroxyindoleacetic acid (5-HIAA) to 5-HT was also significantly increased in the mutant mice (Fig. 4A-D). In contrast, the ratio of 3-methoxy-4hydroxyphenylglycol (MHPG) to NE decreased in the frontal cortex and hippocampus (Fig. $4 A, C$ ), but not in the striatum and thalamus (Fig. $4 B, D$ ), of GluR $\epsilon 4$ mutant mice. These findings suggest that the activities of monoaminergic neuronal systems are altered in adult GluR $\epsilon 4$ mutant mice as a result of the disruption of the GluR $\epsilon 4$ subunit gene.

\section{Locomotor activity in adult GluRe4 mutant mice}

Monoaminergic neuronal systems, particularly dopaminergic and serotonergic neuronal activities, are thought to regulate locomotor activity in animals (Geyer, 1996; Giros et al., 1996; Lucki, 1998; Gainetdinov et al., 1999). To clarify the behavioral influences of altered monoaminergic neuronal function in adult GluR $\in 4$ mutant mice, the locomotor activity in a novel environment was measured for 30 min using digital counters with infrared sensors to record horizontal (locomotion) (Fig. 5A) and vertical (rearing) (Fig. $5 B$ ) activity. Although a time course analysis of locomotor activity revealed no significant difference between wild-type and GluR $\epsilon 4$ mutant mice $\left[F_{(1,19)}=0.192, p=0.9651\right.$ (locomotion); $F_{(1,19)}=1.180 ; p=0.3253$ (rearing)], total counts for both locomotion and rearing during a 30 min observation period were significantly lower in the mutant mice. These results 
A: Frontal Cortex
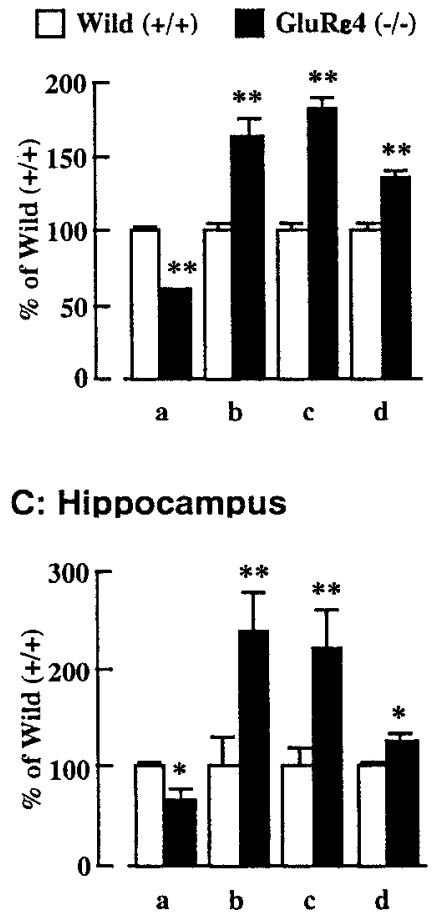

\section{D: Thalamus}

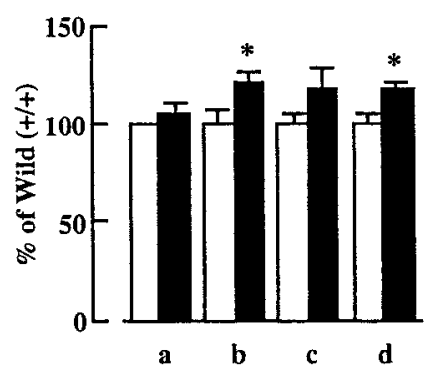

Figure 4. Monoamine metabolism in various regions of the adult GluR $\epsilon 4$ mutant mouse brain. The tissue contents of monoamines and their metabolites in various regions were measured by HPLC with an electrochemical detector. $a$, MHPG/NE; $b$, DOPAC/DA; $c$, HVA/DA; $d$, 5-HIAA/ 5-HT. Each column represents the mean \pm SEM $(n=8) .{ }^{*} p<0.05$ and $* * p<0.01$ versus wild-type $(+/+)$.

suggest that GluR $\epsilon 4$ mutant mice show reduced locomotor activity in a novel environment.

\section{Emotional behavior of adult GluRe4 mutant mice}

We examined the performance of adult GluR $\epsilon 4$ mutant mice in three different paradigms, the elevated plus-maze, light-dark box, and forced swimming tests (Fig. 6), because monoaminergic neuronal systems are also implicated in the regulation of emotional behavior (Schildkraut, 1965; Kim et al., 1997). In the elevated plus-maze test, GluR $\epsilon 4$ mutant mice spent significantly more time exploring the open arms (Fig. 6A) and had more entries into the open arms (GluR $\epsilon 4$ mutant mice, $7.0 \pm 0.5$ entries per 5 min; wild-type mice, $9.3 \pm 0.6$ entries per $5 \mathrm{~min}$ ) than did wild-type mice. In the light-dark box test, GluRe4 mutant mice spent significantly more time in the light box than wild-type mice (Fig. $6 B$ ). The results in the elevated plus-maze and light-dark box tests suggest a reduced psychological anxiety in GluR $\epsilon 4$ mutant mice. The immobility time in the forced swimming test decreased in GluRe4 mutant mice compared with wild-type mice (Fig. 6C). Because immobility in this test is considered to reflect behavioral despair to escape from water (Porsolt et al., 1977a,b, 1978), GluR $\epsilon 4$ mutant mice may have an increased motivation or a reduced susceptibility to stress. It is unlikely that the reduced immobility is attributable to a hyperactivity of the mutant mice because their locomotor activity is rather reduced in a novel environment. Thus, our findings on emotional behavior indicate that GluR $\epsilon 4$ mutant mice may have a reduced susceptibility to stress and/or reduced psychological anxiety.
A: Locomotion
Wild $(+/+)$
GluRe4 (-/-)
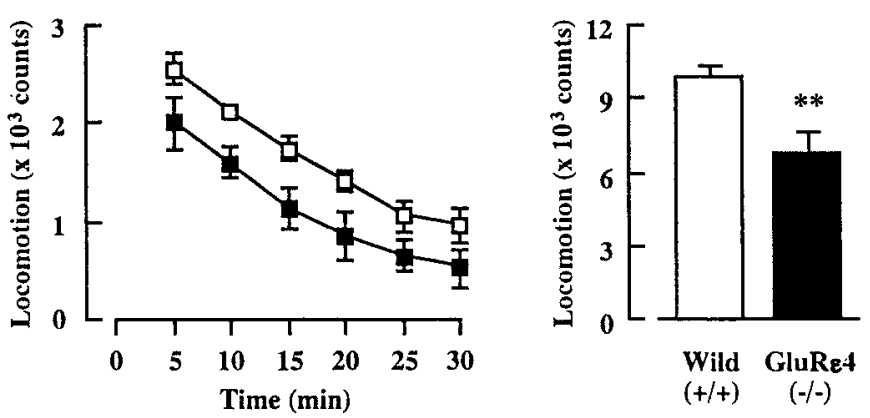

\section{B: Rearing}
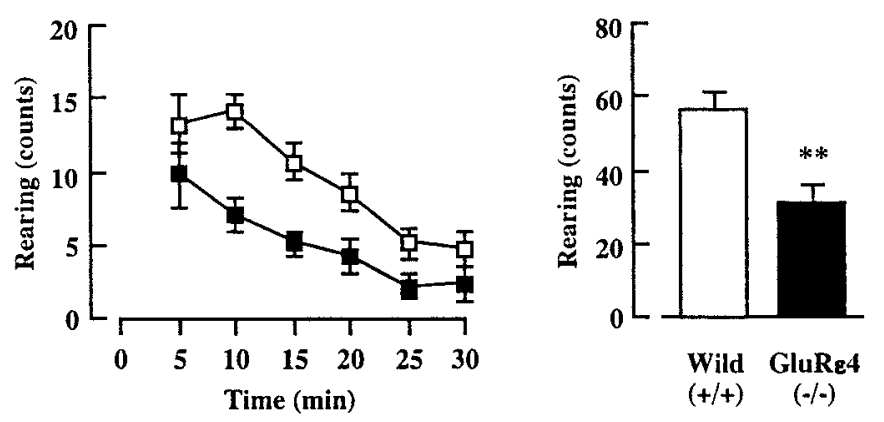

Figure 5. Locomotor activity in a novel environment in adult GluR $\epsilon 4$ mutant mice. Locomotor activity and the number of rearing events in a novel environment were measured every $5 \mathrm{~min}$ for $30 \mathrm{~min}$. Each column represents the mean $\pm \operatorname{SEM}(n=10-11)$. An ANOVA with repeated measures revealed no difference in the time course of locomotion $\left(F_{(1,19)}=0.192 ; p=0.9651\right)$ and rearing $\left(F_{(1,19)}=1.180 ; p=0.3253\right)$. $* * p<0.01$ versus wild-type $(+/+)$.

\section{DISCUSSION}

NMDA receptors are heteromeric assemblies of the GluR $\zeta$ and GluR $\epsilon$ subunits, which exhibit characteristic differences in activities and properties depending on the GluR $\epsilon$ subunits involved, such as affinity for agonists, channel gating kinetics, unitary conductance, and sensitivity to $\mathrm{Mg}^{2+}, \mathrm{Zn}^{2+}$, and antagonist block (Kutsuwada et al., 1992; Monyer et al., 1992; Ishii et al., 1993). Among GluR $\epsilon / \zeta$ heteromeric NMDA receptors, the GluR $\epsilon 4 / \zeta 1$ assembly has the highest apparent affinities for glutamate and glycine (Ikeda et al., 1992), has a very slow channel gating (Monyer et al., 1994), and is less sensitive to $\mathrm{Mg}^{2+}$ block than the GluR $\epsilon 1 / \zeta 1$ and GluR $\epsilon 2 / \zeta 1$ assemblies (Mishina et al., 1993). These findings suggest that the GluR $\epsilon 4$ subunit plays an important role in synaptic transmission in the early stages of brain development, because this subunit is abundant in the embryonic diencephalon and abruptly disappears in the postnatal forebrain (Watanabe et al., 1992; Monyer et al., 1994). To demonstrate the physiological significance of the GluR $\epsilon 4$ subunit in vivo, Ikeda et al. (1995) generated mutant mice without this subunit by a genetargeting recombination technique. In the present study, we investigated the altered neuronal functions of the mutant mice in adulthood.

In $\left[{ }^{3} \mathrm{H}\right] \mathrm{MK}-801$ binding and ${ }^{45} \mathrm{Ca}^{2+}$ uptake through the NMDA receptors under various conditions, an impairment of NMDA receptor function was demonstrated in the forebrain (whole brain minus the cerebellum and brainstem) of adult GluR $\epsilon 4$ mutant mice. Furthermore, a reduction in GluR $\zeta$ subunit protein, but not GluRe1 and GluRe2 subunit proteins, in the 
A: Plus-maze

Figure 6. Emotional behavior of adult GluR $\epsilon 4 \mathrm{mu}-$ tant mice. $A$, Elevated plus-maze test; the frequencies of entries to open and closed arms were recorded for 5 min. $B$, Light-dark box test; the amounts of time spent in the light and dark boxes were measured for $10 \mathrm{~min}$. $C$, Forced swimming test; the duration of immobility was measured for $10 \mathrm{~min}$. The data represent the mean $\pm \operatorname{SEM}(n=8-10) . * * p<0.01$ and $*_{* *} p<0.001$ versus corresponding wild-type $(+/+)$.

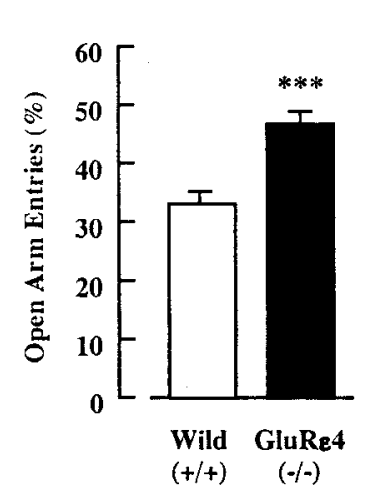

B: Light-dark box

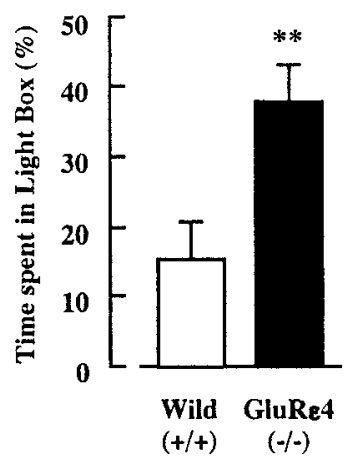

C: Forced swimming

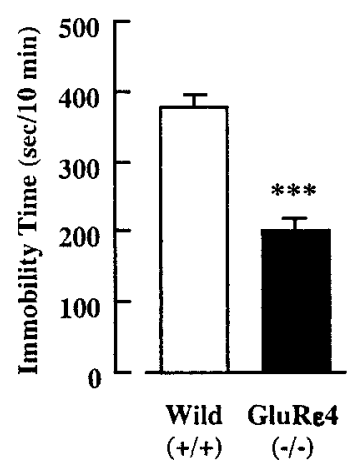

frontal cortex and striatum of the mutant mice was also evident by Western blot analysis. The expression of the GluR $\zeta$ subunit did not change, however, in the hippocampus and thalamus. A similar modification of the GluR subunit expression has been demonstrated in mice lacking the GluR $\zeta$ subunit (Forrest et al., 1994) or overexpressing the GluR $\epsilon 4$ subunit (Okabe et al., 1998). Therefore, it is suggested that the impairment of NMDA receptor function in adult GluR $\epsilon 4$ mutant mice is associated with an alteration of NMDA receptor subunit composition, that is, a reduction of GluR $\zeta$ subunit expression in the frontal cortex and striatum attributable to the disruption of the embryonic GluR $\epsilon 4$ subunit. Alternatively, because the GluR $\zeta$ subunit is an essential molecule for functional NMDA receptors in vivo, which are composed by assembly of four or five GluR subunits, including at least two of the GluR $\zeta$ subunits (Laube et al., 1998; Hawkins et al., 1999), the reduction of GluR $\zeta$ subunit protein might result in fewer functional NMDA receptors per se, without alterations of subunit composition in the receptors. In addition, our findings suggested that the expression of NMDA receptor subunits is regulated interdependently during the development of the brain in a region-specific manner. Thus, the embryonic GluR $\epsilon 4$ subunit may play a role in the regulation of NMDA receptor function in adulthood. To ascertain precisely where in the forebrain the NMDA receptor function is altered, an autoradiographic analysis of $\left[{ }^{3} \mathrm{H}\right] \mathrm{MK}-801$ binding is necessary. Moreover, it remains to be determined, however, why the expression of the GluR $\zeta$ subunit in GluR $\epsilon 4$ mutant mice was downregulated in the frontal cortex and striatum but not other regions of the brain.

In the postmortem brain analysis, GluR $\epsilon 4$ mutant mice showed reduced monoamines and their metabolite contents in the hippocampus. They also showed an increase in both DA and 5-HT metabolism in the frontal cortex, striatum, hippocampus, and thalamus. The alteration to monoaminergic neuronal systems was greatest in the hippocampus among the regions examined, including the frontal cortex, striatum, and thalamus. Thus, in monoaminergic neuronal systems of adult GluR $\epsilon 4$ mutant mice, it is likely that the hippocampus is most severely influenced by a lack of the embryonic GluR $\epsilon 4$ subunit.

The mechanisms responsible for the functional alteration of monoaminergic neuronal systems in adult GluR $\epsilon 4$ mutant mice remain to be determined. It is of interest that rats with neonatal excitotoxic lesions in the ventral hippocampus exhibit hyperfunction of dopaminergic and hypof unction of glutamatergic neuronal systems in adulthood (Schroeder et al., 1999), which resemble the increase of DA metabolism and malfunction of NMDA receptors in adult GluR $\epsilon 4$ mutant mice. It has been proposed that hyper- function of dopaminergic neuronal system in the hippocampuslesioned rats is attributable to an impairment of neuronal development induced by the loss of synaptic connections between the medial prefrontal cortex and ventral hippocampus as a result of excitotoxic lesions of the hippocampus during the neonatal period (Lipska et al., 1993; Schroeder et al., 1999). In GluR $\epsilon 4$ mutant mice, there are no alteration of NMDA receptor subunit levels in the hippocampus (present study) and no obvious histological abnormalities in any region, including the hippocampus on Nissl staining (Ikeda et al., 1995). Therefore, we consider that there may be an impairment of synapse formation connecting the hippocampus and other brain regions in GluR $\epsilon 4$ mutant mice, because previous studies have suggested a role of NMDA receptors in neuronal development (Scheetz and Constantine-Paton, 1994; Contestabile, 2000). Additional study is required to address this possibility.

Alternatively, it may be attributable to the results of NMDA receptor malfunction in adult GluR $\epsilon 4$ mutant mice, because the pharmacological blockade of NMDA receptors in vivo either directly or indirectly results in an altered neuronal activity in monoaminergic neuronal systems, particularly dopaminergic and serotonergic neuronal systems (Hiramatsu et al., 1989; Imperato et al., 1990; Miller and Abercrombie, 1996). Moreover, we provided recently genetic evidence that GluR $\epsilon 1$ mutant mice with reduced NMDA receptor function exhibit an increase in dopaminergic and serotonergic neuronal activities in the frontal cortex and striatum (Miyamoto et al., 2001). In fact, an impairment of NMDA receptor function in the forebrain was evident as a significant decrease of $\left[{ }^{3} \mathrm{H}\right] \mathrm{MK}-801$ binding and ${ }^{45} \mathrm{Ca}^{2+}$ uptake through the NMDA receptors in adult GluR $\epsilon 4$ mutant mice.

It has been demonstrated that GluR $\epsilon 4$ mutant mice show a reduction of spontaneous locomotor activity (Ikeda et al., 1995). Consistent with this finding, reduced locomotor activity in the mutant mice was observed in the present study. Moreover, we found a change in the emotional behavior of GluR $\epsilon 4$ mutant mice. The mutant mice exhibited less susceptibility to psychological and physiological stress induced in the elevated plus-maze, light-dark box, and forced swimming tests. It is considered that locomotor activity and emotional behavior are regulated by the homeostatic balance of activity among monoaminergic neuronal systems (Schildkraut, 1965; Geyer, 1996; Giros et al., 1996; Kim et al., 1997; Lucki, 1998; Gainetdinov et al., 1999). In GluRe4 mutant mice, a significant increase in DA and 5-HT metabolism in the frontal cortex, striatum, hippocampus, and thalamus was evident. Thus, the reduction in locomotor activity and susceptibility to stress may be attributed to the altered monoaminergic, 
especially dopaminergic and serotonergic, neuronal functions in the mutant mice. However, alteration of neuronal functions in GABAergic neuronal system must be considered, because agonistic modulators of $\mathrm{GABA}_{\mathrm{A}}$ receptors are effective in reducing emotional behaviors in the elevated plus-maze and light-dark box tests (Lister, 1987; Dalvi and Rodgers, 1996; Chaouloff et al., 1997).

Interestingly, a previous study demonstrated that the performance of GluR $\epsilon 4$ mutant mice was not different from that of heterozygous mice as control group in the elevated plus-maze and light-dark box tests (Ikeda et al., 1995). It is possible that significant changes in emotional behavior could not be detected because homozygous GluR $\epsilon 4$ mutant mice were compared with heterozygous littermates. Alternatively, the inconsistency between the two studies is attributable to the difference in the age of the mutant mice used. We used GluR $\epsilon 4$ mutant mice at 3 months of age in this study, whereas the previous study examined mutant mice at postnatal day 26 (P26) or P28. The GluRe4 subunit mRNA is mainly expressed from embryonic day 13 through P14 in mouse brain (Watanabe et al., 1992). Considering that disruption of the GluR $\epsilon 4$ subunit may affect the maturation of brain, the function of the CNS in mutant mice is more stable at 3 months than at 4 weeks, which is just after the weaning period. Because different behavioral effects of the GluR $\epsilon 4$ subunit gene disruption in juvenile and adult mice are of special interest, additional studies are required to examine whether there is a critical age when GluR $\epsilon 4$ mutant mice exhibit less susceptibility to psychological and physiological stress.

In summary, adult mice lacking the embryonic GluR $\epsilon 4$ subunit had dysfunctional NMDA receptors, possibly attributable to changes in the receptor subunit composition or reduction of functional NMDA receptors without alterations of subunit composition. The mutant mice showed altered emotional behavior, which is probably attributable to a change in monoaminergic neuronal activities.

\section{REFERENCES}

Chaouloff F, Durand M, Mormede P (1997) Anxiety- and activityrelated effects of diazepam and chlordiazepoxide in the rat light/dark and dark/light tests. Behav Brain Res 85:27-35.

Contestabile A (2000) Roles of NMDA receptor activity and nitric oxide production in brain development. Brain Res Rev 32:476-509.

Dalvi A, Rodgers RJ (1996) GABAergic influences on plus-maze behaviour in mice. Psychopharmacology 128:380-397.

Ebralidze AK, Rossi DJ, Tonegawa S, Slater NT (1996) Modification of NMDA receptor channels and synaptic transmission by targeted disruption of the NR2C gene. J Neurosci 16:5014-5025.

Forrest D, Yuzaki M, Soares HD, Hg L, Luk DC, Sheng M, Stewart CL, Morgan JI, Connor JA, Curran T (1994) Targeted disruption of NMDA receptor 1 gene abolishes NMDA response and results in neonatal death. Neuron 13:325-338.

Gainetdinov RR, Wetsel WC, Jones SR, Levin ED, Jaber M, Caron MG (1999) Role of serotonin in the paradoxical calming effect of psychostimulants on hyperactivity. Science 283:397-401.

Geyer MA (1996) Serotonergic functions in arousal and motor activity. Behav Brain Res 73:31-35.

Giros B, Jaber M, Jones SR, Wightmann RM, Caron MG (1996) Hyperlocomotion and indifference to cocaine and amphetamine in mice lacking the dopamine transporter. Nature 379:606-612.

Glowinski J, Iversen LL (1966) Regional studies of catecholamines in the rat brain. I. The disposition of $\left[{ }^{3} \mathrm{H}\right]$ norepinephrine, $\left[{ }^{3} \mathrm{H}\right]$ dopamine and $\left[{ }^{3} \mathrm{H}\right]$ dopa in various regions of the brain. J Neurochem 13:655-669.

Hawkins LM, Chazot PL, Stephenson FA (1999) Biochemical evidence for the co-association of three $N$-methyl-D-aspartate (NMDA) R2 subunits in recombinant NMDA receptors. J Biol Chem 274:27211-27218.

Hiramatsu M, Cho AK, Nabeshima T (1989) Comparison of the behavioral and biochemical effects of the NMDA receptor antagonists, MK801 and phencyclidine. Eur J Pharmacol 166:359-366.

Hollmann M, Heinemann S (1994) Cloned glutamate receptors. Annu Rev Neurosci 17:31-108.

Ikeda K, Nagasawa M, Mori H, Araki K, Sakimura K, Watanabe M,
Inoue Y, Mishina M (1992) Cloning and expression of the $\epsilon 4$ subunit of the NMDA receptor channel. FEBS Lett 313:34-38.

Ikeda K, Araki K, Takayama C, Inoue Y, Yagi T, Aizawa S, Mishina M (1995) Reduced spontaneous activity of mice defective in the $\epsilon 4$ subunit of the NMDA receptor channel. Mol Brain Res 33:61-71.

Imperato A, Scrocco MG, Bacchi S, Angelucci L (1990) NMDA receptors and in vivo dopamine release in the nucleus accumbens and caudatus. Eur J Pharmacol 187:555-556.

Ishii T, Moriyoshi K, Sugihara H, Sakurada K, Kadotani H, Yokoi M, Akazawa C, Shigemoto R, Mizuno N, Masu M, Nakanishi S (1993) Molecular characterization of the family of the $N$-methyl-D-aspartate receptor subunits. J Biol Chem 268:2836-2843.

Kim JJ, Shih JC, Chen K, Chen L, Bao S, Maren S, Anagnostaras SG, Fanselow MS, De Maeyer E, Seif I, Thompson RF (1997) Selective enhancement of emotional, but not motor, learning in monoamine oxidase A-deficient mice. Proc Natl Acad Sci USA 94:5929-5933.

Kiyama Y, Manabe T, Sakimura K, Kawakami F, Mori H, Mishina M (1998) Increased thresholds for long-term potentiation and contextual learning in mice lacking the NMDA-type glutamate receptor $\epsilon 1$ subunit. J Neurosci 18:6704-6712.

Kutsuwada T, Kashiwabuchi N, Mori H, Sakimura K, Kushiya E, Araki K, Meguro H, Masaki H, Kumanishi T, Arakawa M, Mishina M (1992) Molecular diversity of the NMDA receptor channel. Nature 358:36-41.

Kutsuwada T, Sakimura K, Manabe T, Takayama C, Katakura N, Kushiya E, Natsume R, Watanabe M, Inoue Y, Yagi T, Aizawa S, Arakawa M, Takahashi T, Nakamura Y, Mori H, Mishina M (1996) Impairment of suckling response, trigeminal neuronal pattern formation, and hippocampal LTD in NMDA receptor $\epsilon 2$ subunit mutant mice. Neuron 16:333-344.

Laube B, Kuhse J, Betz H (1998) Evidence for a tetrameric structure of recombinant NMDA receptors. J Neurosci 18:2954-2961.

Li Y, Erzurumlu RS, Chen C, Jhaveri S, Tonegawa S (1994) Whiskerrelated neuronal patterns fail to develop in the trigeminal brainstem nuclei of NMDAR1 knock-out mice. Cell 76:427-437.

Lipska BK, Jaskiw GE, Weinberger DR (1993) Postpubertal emergence of hyperresponsiveness to stress and to amphetamine after neonatal excitotoxic hippocampal damage: a potential animal model of schizophrenia. Neuropsychopharmacology 9:67-75.

Lister RG (1987) The use of a plus-maze to measure anxiety in the mouse. Psychopharmacology 92:180-185.

Lowry OH, Rosebrough NJ, Farr AL, Randall RJ (1951) Protein measurement with the folin phenol regent. J Biol Chem 193:265-275.

Lucki I (1998) The spectrum of behaviors influenced by serotonin. Biol Psychiatry 44:151-162.

Mayer ML, Westbrook GL (1987) The physiology of excitatory amino acids in the vertebrate central nervous system. Prog Neurobiol 28:197-276.

Miller DW, Abercrombie ED (1996) Effects of MK-801 on spontaneous and amphetamine-stimulated dopamine release in striatum measured with in vivo microdialysis in awake rats. Brain Res Bull 40:57-62.

Mishina M, Mori H, Araki K, Kushiya E, Meguro H, Kutsuwada T, Kashiwabuchi N, Ikeda K, Nagasawa M, Yamazaki M, Masaki H, Yamakura T, Morita T, Sakimura K (1993) Molecular and functional diversity of the NMDA receptor channel. Ann NY Acad Sci 707:136-152.

Miyamoto Y, Yamada K, Noda Y, Mori H, Mishina M, Nabeshima T (2001) Hyperfunction of dopaminergic and serotonergic neuronal systems in mice lacking the NMDA receptor $\epsilon 1$ subunit. J Neurosci 21:750-757.

Monyer H, Sprengel R, Schoepfer R, Herb A, Higuchi M, Lomeli H, Burnashev N, Sakmann B, Seeburg PH (1992) Heteromeric NMDA receptors: molecular and functional distinction of subtypes. Science 256:1217-1221.

Monyer H, Burnashev N, Laurie D, Sakmann B, Seeburg PH (1994) Developmental and regional expression in the rat brain and functional properties of four NMDA receptors. Neuron 12:529-540.

Nakanishi S, Masu M (1994) Molecular diversity and functions of glutamate receptors. Annu Rev Biophys Biomol Struct 23:319-348.

Noda Y, Yamada K, Furukawa H, Nabeshima T (1995) Enhancement of immobility in a forced swimming test by subacute or repeated treatment with phencyclidine: a new model of schizophrenia. Br J Pharmacol 116:2531-2537.

Noda Y, Miyamoto Y, Mamiya T, Kamei H, Furukawa H, Nabeshima T (1998) Involvement of dopaminergic system in phencyclidine-induced place preference in mice pretreated with phencyclidine repeatedly. J Pharmacol Exp Ther 286:44-51.

Okabe S, Collin C, Auerbach JM, Meiri N, Bengzon J, Kennedy MB, Segal M, McKay RDG (1998) Hippocampal synaptic plasticity in mice overexpressing an embryonic subunit of the NMDA receptor. J Neurosci 18:4177-4188.

Pin JP, Duvoisin R (1995) The metabotropic glutamate receptors: structure and functions. Neuropharmacology 34:1-26.

Porsolt RD, Bertin A, Jalfre M (1977a) Behavioural despair in mice: a primary screening test for antidepressants. Arch Int Pharmacodyn Ther 229:327-336. 
Porsolt RD, Le Pichon M, Jalfre M (1977b) Depression: a new animal model sensitive to antidepressant treatments. Nature 266:730-732.

Porsolt RD, Anton G, Blavet N, Jalfre M (1978) Behavioural despair in rats: a new model sensitive to antidepressant treatments. Eur J Pharmacol 47:379-391.

Sakimura K, Kutsuwada T, Ito I, Manabe T, Takayama C, Kushiya E, Yagi T, Aizawa S, Inoue Y, Sugiyama H, Mishina M (1995) Reduced hippocampal LTP and spatial learning in mice lacking NMDA receptor $\epsilon 1$ subunit. Nature 373:151-155.

Scheetz AJ, Constantine-Paton M (1994) Modulation of NMDA receptor function: implications for vertebrate neural development. FASEB J $8: 745-752$

Schildkraut JJ (1965) The catecholamine hypothesis of affective disorders: a review of supporting evidence. Am J Psychiatry 122:509-522.

Schroeder H, Grecksch G, Becker A, Bogerts B, Hoellt V (1999) Alterations of the dopaminergic and glutamatergic neurotransmission in adult rats with postnatal ibotenic acid hippocampal lesion. Psychopharmacology 145:61-66.

Watanabe M, Inoue Y, Sakimura K, Mishina M (1992) Developmental changes in distribution of NMDA receptor channel subunit mRNAs. NeuroReport 3:1138-1140.

Yamada K, Iida R, Miyamoto Y, Saito K, Sekikawa K, Seishima M, Nabeshima T (2000) Neurobehavioral alterations in mice with a targeted deletion of the tumor necrosis factor-alpha gene: implications for emotional behavior. J Neuroimmunol 111:131-138.

Yoneda Y, Ogita K (1989) Labeling of NMDA receptor channels by $\left[{ }^{3} \mathrm{H}\right] \mathrm{MK}-801$ in brain synaptic membranes treated with Triton X-100. Brain Res 499:305-314.

Yoneda Y, Ogita K (1991) Heterogeneity of the $N$-methyl-D-aspartate receptor ionophore complex in rat brain, as revealed by ligand binding techniques. J Pharmacol Exp Ther 259:86-96. 